\title{
Interactive comment on "A General Analytical Model for Head Response to Oscillatory Pumping in Unconfined Aquifers: Consider the Effects of Delayed Gravity Drainage and Initial Condition" by Ching-Sheng Huang et al.
}

Ching-Sheng Huang et al.

hdyeh@mail.nctu.edu.tw

Received and published: 5 January 2019

I have now read the revised manuscript and responses to review comments. The authors have assiduously incorporated my suggested revisions, and I believe the manuscript is suitable for publication in its present form. Their submission provides a more robust approach for evaluating periodic testing in unconfined aquifers by extending parameter estimation to vertical anisotropy and delayed drainage. As such, it extends the utility and practicality of periodic aquifer testing. 
Response: We very appreciate your time and efforts in providing valuable comments which do improve the quality and readability of our manuscript.

Interactive comment on Hydrol. Earth Syst. Sci. Discuss., https://doi.org/10.5194/hess-2018482, 2018.

Interactive

comment 